\title{
IUGS FINANCIAL STATEMENT FOR 1985, BUDGET FOR 1986
}

\section{Receipts and Expenditures for 1985 compared to 1984 and estimates for 1986 (Information provided by IUGS Treasurer, Dr. J.A. Reinemund, see Note 1)}

RECEIPTS

- Transfers from Unesco for IGCP contracts (See Note 2)

- Hembership dues (See Note 3)

- Special grants and contracts (See Note 4)

- Allocations from ICSU (See Note 5)

- Income from publications:

- Episodes subscrictions and related income

- Royalties and IUGS Publications sales

Bank interest and gain on exchange

Hiscellaneous receipts (See Note 6)

\section{PAYMENTS}

- Scientific activities

- IGCP (See Note 7)

- IGCP supplements from IUGS (See Note 8)

- IUGS Commissions, Committees (See Schedule A)

- Payments on special contracts (See Note 9)

- Research bevelopment Program (See Note 10)

- Symposia and workshops (See Note [1)

- IUGS Affiliated Organizations (See Schedule B)

- Inter-Union Commission on the Lithosphere

- Representation at scientific meetings

- Routine meetings

- 1985: Executive Committee meeting, Rabat (See Note 13)

- 1986: Executive Committee meeting, Washington

- Publications

- Episodes printing and related costs (See Note 14)

- Other IUGS publications: printing costs

- Promotion and displays

- Miscellaneous costs

- Administrative expenses

- Salaries and related charges (See Note 14)

- Operating costs and supplies

- Viscellaneous charges

- Bank charges, loss on exchange

- Payments to ICSU

- IUGS annual contribution to ICSU (See Note 5)

- IUGS contribution to Committee on the Teaching of Science

- IUGS dues to ICSU (1984), ICSTI (1985)

Episodes account (Ottawa)

Past President's account (Bonn)

Secretary-General's account (Trondheim) (See Note 15)

Past Secretary-General's account (Paris) (See Note 6)

Past President's account (Zurich)

Treasurer's operational account (Reston) (See Note 15)

ICGS reserve account (Reston) (see Note 6)

TOTAL

126,824

10,730

51,342

31,686

48,480

25,200

15,000

14,811

30,562

3,181

4,257

2,477

27,843

20,408

8,429

1,542

4,316

800

TOTAL

360

$\$ \$ \underline{485,736}$

976

675

144

3,200

953

28,492

49,057

$\$ 83,497$
1985

(\$US)

175,880

183,579

54,700

24,219

42,625

11,517

5,388

26,062

$\$ 523,970$
Budget

for

1986

(\$LS)

200,000

170,000

50,000

22,000

41,000

10,0000

4,000

18,000

$\$ \overline{515,000}$

\section{SUMMARY}

Accounts receivable December 31 (See Note 15)

Accounts payable on December 31

Difference

70,805

13,847

$\overline{5} \overline{6,958}$

77,576

$+5,921$

83,497

56,958

$\$ 1 \longdiv { 4 0 , 4 5 5 }$
194,596

10,500

60,238

5,000

11,624

$2 y, 788$

18,500

23,000

6,110

13,968

24,752

11,425

7,383

828

34,648

18,508

918

386

4,263

500

$\$ 476,935$

21,334

806

$-16,878$

807

70,262

54,201

$\$ \underline{\underline{30,532}}$

Accumulated balance at January I

Plus excess of receipts over expenditures

Accumulated balance at December 31

Plus difference between accounts receivable and payable

NET FINANCIAL ASSETS AT DECEMBER 31

71,634

21,034

$\overline{50,600}$

83,497

47,035

$1 \longdiv { 3 0 , 5 3 2 }$

50,600

$\$ 1 \overline{81,132}$

210,000

10,000

71,500

14,000

15,000

15,000

20,500

23,000

7,000

20,000

30,000

8,000

4,000

2,500

35,000

22,000

1,600

400

4,600

500

400

$\$ \underline{515,000}$ 


\section{NOTES TO THE 1984 AND 1985 FINANCIAL STATEMENT}

Note 1: This Statement has been prepared by the Treasurer in accordance with the Statutes and Bylaws of the Union. Receipts and payments have been recorded in the account books of the IUGS offices. in those offices outside the U.S.A. the accounts have been converted to U.S. dollars at year-end, based on official ICSU rates of exchange at the year end. Receipts and payments involving exchanges of eurrency during the year have used the official lCsu rate of exchange at the time of transaction.

in order to provide a basis for comparison, comparable information on receipts and payments is included for 1984, as well as the estimated income and project expenditures (budget) for 1986. This statement is a consolidation of information from accounts maintained solely by IUGS in Ottawa, Bonn, Zurich, Trondheim, Paris, and Reston, but does not include joint-use local currency accounts in iloscow and Sydney.

This statement does not reflect the costs borne by member countries in support of activities and operations of the Union except for those costs covered by transfers of funds under special grants listed in Note 4. Also, this statement does not show details of accounts receivable or payable at the end of the year.

Note 2: Funds are transferred from Unesco each year under contracts between Unesco and IUGS covering IGCP projects for which allocations are made during the year. However, each year there are delays in transfer of budgeted funds from Unesco for some projects that do not start at the scheduled time, as well as carry-over receipts from Unesco for projects funded in the previous year. The total funds received in 1985 included $\$ 10,305$ in allocations for contracts issued in 1984. 1986 estimates are based on assumptions that some amounts allocated by Unesco for IGCP projects in 1986 will not be received until 1987 , but that carry-over allocations for 1986 will be received by IUGS during 1986 . Total amount tentatively budgeted by Unesco for 1986 is $\$ 247,000$.

Note 3: Member countries pay annual con tributions according to their selected category of membership as outlined in the following table:

$\begin{array}{lllllllll}\text { Category } & \mathrm{l} & 2 & 3 & 4 & 5 & 6 & 7 & 8\end{array}$

Category

$\begin{array}{lllllllll}\text { Contribution* } & 1 & 2 & 4 & 7 & 12 & 20 & 35 & 70\end{array}$ (*valued at U.S. $\$ 300$ per unit as of July 10,1980 ) The 1985 receipts figure includes $\$ 15,296$ paid in 1985 covering membership fees for years prior to 1985 , and $\$ 11,593$ in advance payments covering 1986 membership fees.

Note 4: Receipts from special grants and contracts during 1985 included:

- Unesco contract for remote sensing program in Africa

Unesco contract for remote sensing workshop in Brazil

- Unesco contract for deposit nodelling workshop in Sucan

y,700

Unesco contract for deposit modelling workshop in Philippines

Canada grant for President's office

expense

10,000

for Treasurer's of fice expenses

TOTAL

$\frac{500}{54,700}$

Note 5: IUGS received $\$ 15,219$ from ICSU in 1985 as apportioned amount of the Unesco subvention to ICSU. IUGS also received $\$ 9,000$ from ICSU in 1985 as supplemental grants to support research projects under the IUGS Research Development Program. IUGS pays an annual subvention to ICSU based on $2.5 \%$ of receipts for IUGS membership fees.
Note 6: Funds in this category included deposits of $\$ 4,380$ in refunds of unspent allocation to Paris account, $\$ 14,368$ in refunds of unspent 1984 and 1985 allocations to lGCP projects, and $\$ 2,170$ in unspent funds from COGEOJATA, plus $\$ 5,144$ in dividends and increased market value of IUGS reserves.

Note 7: Funds transferred in 1985 included $\$ 178,146$ to $\mathrm{KGCP}$ projects authorized in 1985 and $\$ 9,247$ to $\mathrm{lGCP}$ projects authorized in 1984 . Also included in the total were unspent funds transferred back to Uneseo amounting to $\$ 4,603$ from 1985 projects and $\$ 2,600$ from 1984 projects.

Note 8: IUGS supplements in 1985 were distributed to seven IGCP projects having high priority funding requirements.

Note 9: Funds paid in 1985 were in support of the Geologie Applications of Remote Sensing (GARS) program in Africa under a special contract between Unesco and IUGS (see also Item 1 in Note 4).

Note 10: Funds paid in 1985 included $\$ 3,500$ for research in the Pannonian basin, $\$ 3,588$ to help organize research a basin analysis project in Southeast Asia, $\$ 1,792$ for research on mineralization in Andean volcanic rocks, and $\$ 2,744$ for expenses of the Research Development Board.

Note 11: Funds in 1985 included $\$ 4,287$ for deposit modelling presentations in Sudan, $\$ 10,235$ for a deposit modelling workshop in the Philippines, and $\$ 14,522$ for a remote sensing workshop in Brazil, all involving support under contracts with Uneseo.

\section{SCHEDULE A}

PAYMENTS TO COMMISSIONS, BOARDS AND COMMITTEES (a)

\begin{tabular}{|c|c|c|c|}
\hline & $\begin{array}{l}1984 \\
(\$ \mathrm{US})\end{array}$ & $\begin{array}{l}1985 \\
\text { (\$US) }\end{array}$ & $\begin{array}{l}1986 \\
(\$ \cup S)\end{array}$ \\
\hline $\begin{array}{c}\text { Commission on Igneous } \\
\text { and Metamorphic }\end{array}$ & & & \\
\hline Petrogenesis & 2,000 & 2,500 & 3,000 \\
\hline Commission on Geological & & & \\
\hline Documentation & & 2,500 & 1,500 \\
\hline Commission on & & & \\
\hline Geology Teaching & & & 500 \\
\hline $\begin{array}{l}\text { Commission on the History } \\
\text { of Geological Sciences }\end{array}$ & 500 & & 1,500 \\
\hline ommission for Marine & & & \\
\hline Geology & 7,000 & 6,000 & 4,500 \\
\hline $\begin{array}{l}\text { Commission on Storage, } \\
\text { Automatic Processing } \\
\text { and Retrieval of }\end{array}$ & & & \\
\hline Geological Data & 4,500 & 5,300 & 7,000 \\
\hline ommission on & & & \\
\hline $\begin{array}{l}\text { Systematics in } \\
\text { Petrology }\end{array}$ & 3,000 & 8,000 & 5,500 \\
\hline $\begin{array}{l}\text { Commission on Tectonics } \\
\text { (See Note 12) }\end{array}$ & 1,500 & 2,000 & \\
\hline ommission on Stratigraph & & & \\
\hline (See Note 1 & 21,100 & 27,450 & 26,000 \\
\hline $\begin{array}{l}\text { Advisory Committee on } \\
\text { Comparative }\end{array}$ & & & \\
\hline Planetology & 2,500 & 2,000 & 3,000 \\
\hline $\begin{array}{l}\text { Standing Committee on } \\
\text { Remote Sensing }\end{array}$ & & & \\
\hline (See Note 12) & 6,242 & 881 & 13,000 \\
\hline Ad Hoc Committee on & & & \\
\hline Sed & 3,000 & 500 & 2,500 \\
\hline Norking Group on & & & \\
\hline Resource & & & \\
\hline Assessme & 51,342 & $\begin{array}{r}3,107 \\
60,238 \\
\end{array}$ & $\begin{array}{r}3,500 \\
\underline{71,500} \\
\end{array}$ \\
\hline
\end{tabular}

(a) Expenditures for Advisory Boards and related activities are included in general listing of payments.
SCHEDULE B

PAYMENTS TO AFFILIATED ORGANIZATIONS

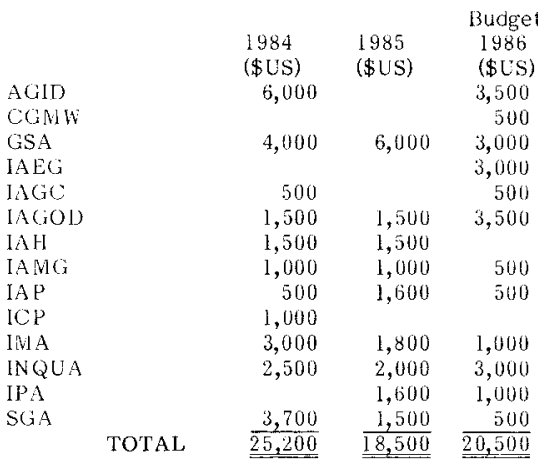

Note 12: Funds allocated to the Commission on Stratigraphy are divided among 24 constituent subcommissions and working groups (see list in Episodes vol. 1983, no.4, p. 67) according to priorities established by the Commission.

Allocation to the Commission on Tectonics in 1986 is pending redefinition of Commission scope and objectives. Funds for Advisory Boards on Publications and Research Development are included in the listing of summary payments for 1985 and budget for 1986. See also Note 10 concerning Research Development expenditures. Funds shown for Standing Committee on Remote Sensing do not include expenditures under special contracts, which are itemized in Notes 9 and 11 .

Some of the budgeted amounts for 1985 as shown in this statement differ from amounts originally allocated by the Executive Committee because of subsequent allocations to meet demonstrated needs.

Note 13: Includes expenditures connected with IUGS seminar on marine geology held in conjunction with the Executive Committee meeting in Rabat.

Note 14: Salary costs for Episodes are shown under "Administrative expenses" inasmuch as the Episodes staff provides considerable service not only for the publication program but also for IUGS publicity, representation, and liaison.

Note 15: In calculating "Accounts receivable" for $1985, \$ 12,500$ in unpaid membership fees for years prior to 1981 have not been included owing to considerable uncertainty that they will be received.

As shown in this listing, the Trondheim account had a deficiency of $\$ 16,878$ as of December 31 , 1985 , pending the transfer of this amount from the Treasurer's operational account in Reston. 